\title{
THE RELATIONSHIP BETWEEN THE SCHOOL PRINCIPALS' LEVEL OF 21ST CENTURY SKILLS AND THEIR CAPABILITY TO MANAGE CHANGE AT SCHOOLS ${ }^{i}$
}

\author{
Mehmet Akif Helvaci ${ }^{1}$, \\ Şirin Yörük ${ }^{2 i i}$ \\ 1Prof. Dr., \\ Faculty of Education, \\ Uşak University, \\ Turkey \\ 2English Language Teacher, \\ National Education \\ Directorate of Uşak Province, \\ Turkey
}

\begin{abstract}
:
The purpose of this research is to determine the relationship between school administrators' levels of 21st century skills and their competencies in managing change, according to teachers' views. Moreover, it was investigated to reveal school administrators 21st century skills levels and their proficiency in managing change. In addition, it is aimed to reveal school administrators their 21st century skill levels and their proficiency in managing change. 290 teachers in Uşak participated in this quantitative research conducted in the relational survey model. As a research data collection tool, "The 21st Century Education Manager Skills Scale and the School Managers' Ability to Manage Change Scale were used. Correlation analyzes were also conducted along with descriptive statistics in order to determine the 21st century skills levels of school administrators and their proficiency in managing change. According to the results obtained, it has been seen that the 21st century skill levels of school administrators and their proficiency in managing change are at a very high level. Also, it has been determined that there is a high level of positive correlation between school administrators' proficiency levels of 21st century skills and their proficiency in managing change.
\end{abstract}

Keywords: 21st century skills, managing change, the capability of change management, school principals

\footnotetext{
i This article represents a part of a thesis.

ii Correspondence: email sirin arslan@yahoo.com, mehmetakif.helvaci@usak.edu.tr
} 


\section{Introduction}

In the 21st century, digital technologies have been developed rapidly and have become an indispensable part of social life in many areas. Today, the production-based economy has left its place to knowledge and innovation. Especially in the field of education, the development of individuals has been the focus. Because the main purpose of contemporary societies; is to raise individuals in a healthy way for the future and to meet the needs of the age (Altunbay, 2015). In the face of developing and changing world conditions, changes have occurred in the field of education as well as in all fields, and within the scope of these changes, the technologies used in the field of education, students and teachers have taken part in some transformation (Orhan-Göksün ve AşkımKurt, 2017).

In general, 21st century skills are expressed as competencies that individuals should have and constantly need to develop in the age of information and technology. Many institutions and organizations have made studies to classify qualifications in the 21st century. The most well-known of these is the Partnership for 21st Century Learning. This partnership, created in the United States of America (USA) in 2002, included business representatives, education leaders and policy makers. In our country, in the 21st century skills were first discussed by the Turkish Businessmen's Association (TUSIAD), and studies on the necessary qualifications for the professions of the future were carried out by the Ministry of National Education (MEB). In the light of the "European Qualifications Framework" prepared by the European Parliament, the Ministry of National Education has included these skills in the curriculum as these 8 key competencies with the "National Education Quality Framework" and "Turkey Qualifications Framework" (TTKB, 2017). This change in Turkey is expressed as follows in the 2023 Education Vision:

"The educational approach, which has been called 21st century skills' in recent years and is seen as an indispensable global norm today; It imposes the understanding of the development and maturation of human beings in the light of what they can achieve in the material world, under the name of "acquiring soft skills" such as creativity, communication, teamwork, and critical thinking. In fact, this understanding is now a strategic conceptual framework imported to every corner of the world. At this point, in this continuity that extends from ancient times to modernization, from the industrial revolution to the digital age, where cyber-physical systems, the last point of technological developments, have started to be talked about in every field, it has become much more important to examine the connection between education and philosophy. The education proposal of the 2023 Education Vision for the 21st century is a double-sided reading in the form of the 21st Century Education and Discipline Model. Just gaining skills is not enough to face life. What is required is a maturation, development, progress, change and moral beauty that encompasses and encompasses all universal, local, material, spiritual, 
professional, moral and national values." (MEB 2023 Education Vision Document, 2019)

Today, all countries update their education systems to meet the needs of the 21st century. The education system is a structure with many components. The education system is a human-centered system and affects all other systems. In this sense, education systems are systems that are open to continuous change and transformation according to the requirements of the age. If the education system cannot meet the needs of the age and society, it is doomed to disappear (Erginer, 2006). 21st century School administrators, who play an important role in raising individuals suitable for the age in Turkey, should make an effort to prepare their schools for change and to ensure their personal development as administrators (Drucker, 2014). Researchers have carried out studies on the competencies of school administrators in accordance with the requirements of the age and have carried Katz's three-dimensional approach to an advanced dimension. Within the framework of critical pedagogy that has been emphasized in recent years, new skills such as respect for different cultures and sensitivity to gender equality have come to the fore, and a consensus has been reached that school administrators should acquire agespecific competencies (Annulis \& Gaudet, 2007; Bateman \& Snell, 2004).

It is very important for school administrators to determine the change policy in their schools appropriately, to anticipate the cultural, social and economic obstacles that may occur in the change process, and to develop strategies by taking measures against these obstacles. Today, the rapid change in education and the restructuring efforts of school administrators increase the responsibilities of administrators who are decisionmaking mechanisms in schools. The innovations necessitated by the age have brought along some innovations in education policies. In the 2000s, innovations were experienced in the field of education in Turkey and many regulations and changes were made. School administrators have to keep up with these innovations and manage the change in their institutions. 21st century skills in managing changes are the skills that school administrators should have (Helvac1, 2010). Today, innovative and competitive organizations prefer employees who can produce and manage information themselves, have effective teamwork, have strong communication skills, and can produce solutions to problems (Partnership for 21st Century Skills, 2008). These skills should be possessed by school administrators who lead the change in schools, as other occupational groups should have (Helvac1, 2010).

\section{Literature Review}

\section{1. $21^{\text {st }}$ Century Skills}

In our age, students, teachers and administrators must have some knowledge and skills required by the 21st century in order to keep up with the conditions required by the 21st century and to cope with the difficulties that may be encountered in the future. Not just people: institutions, companies and countries also have to make good future planning. 
For this reason, educational institutions should integrate these skills, called 21st century skills, which are demanded by the business world, into the education system (National Research Council, 2016).

21st century skills, which are shaped around basic issues, are discussed under 3 main headings (Partnership For 21st Century Skills, 2013).

1) Learning and Innovation Skills:
a) Creative Thinking,
b) Critical Thinking,
c) Problem Solving,
d) Communication,
e) Collaboration.

2) Information, Media and Technology Skills:
a) Information Literacy,
b) Information and Communication Technologies Literacy,
c) Media Literacy.

3) Life and Professional Skills:

a) Flexibility and Adaptability,

b) Self-Management,

c) Social Skills,

d) Productivity and Accountability,

e) Leadership.

Creativity; traditionally associated with art and music. But lately creativity; scientific thinking, entrepreneurship, and design are evaluated in a wide range (Sheffield, L., 2013). Institutions have to be creative and innovative in order to adapt to the rapidly occurring changes in the globalizing world. In this sense, it is inevitable for organizations to be creative in terms of competitiveness (Eryllmaz \& Ulusoy, 2015).

Questioning and questioning the future in education dates back to Socrates, who revealed his interlocutors' exams and prejudices. Now, 2400 years later, it looks like a priority for education (Conley, D. 2007). Education administrators should be able to examine the components of the problem and use analysis and synthesis methods effectively to find different solutions while seeking solutions to the problems encountered in the institution. For this reason, school administrators should have the following skills (Cottrell, 2005; Partnership for 21st Century Skills, 2008): a) to be able to reason, b) to analyze the relationship between the parts of the whole, c) to ask the right questions, d) to make effective decisions, e) to be able to make an effective evaluation, f) to analyze and evaluate different solution proposals, g) to synthesize new information, h) to interpret the information obtained as a result of the analysis, i) to have a critical point of view i) to include criticism in decision making, j) to make a problem to be able to use both traditional and innovative methods in its solution.

Communication, defined as sharing thoughts, feelings and ideas in order to create a common ground of meaning and achieve desired results, is a social process and has an important place in people's lives (Metusalem, Belenky \& DiCerbo, 2017). Communication 
is the verbal and written exchange of feelings, thoughts and information between people. School administrators should pay attention to the following in communicating effectively with school staff, students and parents (Partnership for 21st Century Skills, 2008): a) being a good listener, b) using positive body language, c) clear communication, d) use clear language, e) be understandable, f) be motivating, g) be persuasive, $h$ ) to be able to empathize, 1) being able to communicate easily with different people and institutions. Communication is a phenomenon that improves the relationship between people. Communication is the key factor for effective schools. The school administrator should be a good communicator, and use verbal, written and nonverbal communication skills effectively to enlighten, motivate and inspire school staff, students and parents. It should also use the media and technologies effectively in communication.

An important 21st century ability collaboration; the ability to work efficiently and effectively with others is an important skill for success in life. However, cooperation should not be seen as a simple act of working together. Collaboration should arise from the individual's feeling of need to work together to get a better result than he or she would have alone. Moreover, it is a social interaction where the participants decide together, produce the knowledge together, and build it (Barfield, 2016). In our increasingly complex world, the best way to solve problems is to collaborate with people and organizations with different skills and experience. When effective cooperation is established, a much better decision is made than a decision made by one person alone, as decisions will be evaluated from a multiple perspective. However, when an effective cooperation is not established, a much worse decision can be made than the decision of one person (Surowiecki, J., 2005).

Information literacy is finding the right information to solve a problem or, making correct evaluations and using information effectively in an ethical framework (Partnership for 21st Century Skills, 2008). Zurkowski (1974, p. 6) defined information literacy as follows; "A person who is information literate is a person who can use information resources effectively and has the ability to use different information resources, especially in order to find solutions to problems that arise in the business environment." In other words, information literacy is the ability to identify, evaluate and use the right information effectively in order to solve a problem.

Media literacy is the ability to access electronic media messages and print media messages, to make sense of these messages, to evaluate through analysis and synthesis, and to produce content (Aufderheide, 1993). Media Literacy is the ability to access, analyze, evaluate and create media in various forms. Media literacy involves creating messages using technology as well as questioning them. Creating or producing a media message is the most effective way to start developing media literacy, which includes understanding the way messages are created (Öğretir, Özçelik, \& Tuğluk, 2018).

Technology literacy while using digital technologies; to have sufficient knowledge of the legal/ethical framework in using information and to use technology effectively as a tool (Partnership for 21st Century Skills, 2008). According to Shackelford (2007), in our age, individuals should be aware of the extent to which technology affects our lives and 
the developments in technology. For this reason, technology literacy has become an integral part of the education system. Today, there is a need for individuals who are open to technological developments, who can use these technologies effectively, who can interpret the effects of technology, who develop appropriate solutions to technological problems, and who can make sense of the relationship between technology, individual and education.

Individuals with easy adaptation skills; do not have difficulty in adapting to various roles and responsibilities, they do not lose their motivation to work in changing situations (Partnership for 21st Century Skills, 2008). At the same time, individuals with the ability to adapt are flexible in their perspectives on events, and therefore they can easily adapt to change. Individuals who have flexibility and adaptability skills easily adapt to change in their daily lives and do not have difficulty in changing their habits. If the employees and managers of the organization have the ability to be open to new learning and adapt to changes, they will display organizational flexibility behavior (Ceylan, 2001).

İnitiative is a concept that aims to make individuals and institutions perform better by taking responsibility (Akın, 2014). Self-management, on the other hand, is the management of the decision-making process by the employees themselves without external pressure (Beyerlein, 1994).

Social and Intercultural competence is the ability to empathize, understand the emotional state of those people, respect differences, and accept similarities when communicating with people from different ethnicities and different socio-economic levels. In other words, it is to be able to communicate effectively with people from different cultures, to convey messages correctly, to make sense of the messages received, and to ensure the long-term continuation of communication relations with different communication channels (Bush et al., 2001).

Productivity is defined as the ratio of input to output in enterprises and factories. In other words, being productive is the effective use of resources. Since education is a system consisting of input, process, output and evaluation elements, the concept of productivity is also an important concept for the education system. Productivity in education is an important performance indicator (Öğretir \& Tuğluk, 2019). Accountability is the ability of the authorized person to be transparent while performing his/her duty, to be clear to the outside, and to take responsibility when faced with a negative situation (Schater, 2000).

As a school administrator's leadership skill, it is to influence and direct the school personnel with interpersonal communication skills in line with the goals of the school. A leader school administrator guides the staff of the institution while solving their own problems. While realizing the goals of the institution, it acts as the locomotive, makes the personnel aware of their own strength, is honest in relations with the personnel, exhibits ethical behaviors and inspires the employees (Partnership for 21st Century Skills, 2008). 


\subsection{Change Management}

There are many different definitions of change. Change; is defined as the opposite term of continuity or immutability (Özkara, 19). Change is defined as the whole of the changes over time in the dictionary of the Turkish Language Association (Turkish Language Institution Dictionary). Change; is the occurrence of a quantitative or qualitative difference in the old situation or behavior independent of value judgements. It can be both progress and regression (Helvac1, 2010). Knowing which forces urge organizations to change is important in order to manage change effectively. The forces that urge organizations to change can be examined in two groups as external forces and internal forces. External forces are the environmental factors that the organization cannot control, and internal forces are the forces within the organization that can be controlled by the management (Gibson et al., 1991). Organization can be defined as the organization of people coming together for the same purpose, the coordination of these people, and the evaluation of this process. Organizations arise from the need to act together by the nature of human beings (Balc1, 2005). The main purpose of organizations in implementing change is to adapt to the changing and developing internal and external factors and to implement a new structure by increasing the efficiency of the institution and the job satisfaction of the employees (Ülgen, 1993).

Organizations that are aware of the fact that change is inevitable, do not discuss whether change is necessary, but they discuss whether the organizations have developed enough, how to ensure continuity in change, and how organizations will maintain their existence as learning organizations. In other words, organizations are aware that facts such as work, communication, method are in a constant change. Members within the organization have to keep up with this change (Uslu 2006, p.7). Resistance to change has long been recognized as a critical factor influencing success and organizational change effort. Managing the change process effectively and minimizing the resistance to change depends on a preliminary preparation. In this process, first; needs analysis should be done, change planning should be made, general lines suitable for social change should be drawn and then the implementation process should be started (Schalk, 1998).

Dalin et al. $(1993,87)$ classified barriers to change into four groups.

1) Value barriers: These are the situations where the values of the people affected by the change and the values of the change to be realized do not match with each other.

2) Power balances: Resistance behavior is inevitable in situations where the change causes the people affected by the change to lose power.

3) Psychological obstacles: Resistance occurs when it takes people out of their comfort zone they are used to and when it negatively affects people's psychosocial conditions.

4) Implementation barriers: If the people affected by the change have to acquire new skills with the change to be realized and there are some inadequacies in reaching the necessary resources, they tend to resist the change. 
Although every organization is different, the most important approaches used to overcome resistance to change can be listed as follows;

1) Education and communication: Informing and educating employees about change in advance, and effective communication with employees helps stakeholders see the rationale for change, which reduces criticism and resistance. If people's working styles or habits need to change, employees should be informed rather than automatically thrown into change (Kuzhda, 2013).

2) Participation: When employees are involved in decision making, it can help motivate the workforce. However, this is a time-consuming effort that involves multiple consultations to get the workforce to accept this change. Employee participation in change always facilitates the change process. Employees' participation in the decision process will motivate them to adapt to change (Pashchenko, 2014).

3) Facilitation and support. Another way managers can deal with potential resistance to change is to be supportive. In this process, it may include support such as providing training on new skills, giving permission to employees after a difficult period, or just listening to employees (Stepanenko, 2016).

4) Negotiations and agreement: Another way to deal with resistance is to offer incentives to active or potential resistance. For example, management may offer a higher pay rate for an employee's work rule change; can increase an individual's pensions in exchange for early retirement (Kuzdha, 2016)

5) Collaborate: It involves giving employees their desired role in the design or implementation of the change. Choosing a group involves playing a key role in the design or implementation of a change to one of its leaders or someone they respect (Kuzmin, 2014).

6) On and off forcing. This is a strategy used as a last resort if employees resist change. Pressure can be used by managers to force staff to accept change. Examples include employee transfer, layoffs, or non-promotion (Kuzdha, 2016).

Change management is a formal process for organizational change that includes a systematic approach and application of knowledge. Change management means the recognition and adoption of corporate strategies, structures, procedures and technologies to keep up with changes arising from internal and external conditions (Helvacl, 2010).

The most important task in realizing social change falls on schools. People acquire the knowledge, skills and competencies necessary for change in schools. For this reason, schools play a key role as an organizational system in raising individuals who will shape the future (Hargreaves 1991). In the past years, school administrators have made an effort to maintain the current order, but in the 21st century, with the inevitable changes, they strive to increase their resistance to change and their ability to cope with this resistance (Güneş, 1995). School administrators have been the people who lead the change efforts in schools for the implementation and coordination of the planned changes (Helvac1, 2010). 


\section{Research Objective}

When the literature is examined, it is seen that there are many studies that examine the relationship of school administrators with many different variables such as 21 st century skills and leadership styles, communication skills, problem solving skills, and technological competencies. However, no study has been found that examines the relationship between school administrators' 21st century skills and school administrators' ability to manage change. This study will contribute to the literature in this aspect.

In this study, the relationship between school administrators' 21st century skills and their ability to manage change in schools, according to the opinions of teachers working in Uşak, was tried to be determined and answers were sought for the following research questions in line with this purpose.

1) According to the teachers' opinions, at what level of the 21 st century skills do school administrators have?

2) According to teachers' opinions, at what level of competencies to manage change do school administrators have?

3) Is there a relationship between the level of having $21^{\text {st }}$ century skills and the competencies of managing change in schools?

\section{Material and Methods}

\subsection{Research Model}

This research is a quantitative research supported by a relational survey model to determine the relationship between school administrators' 21st century skills and their ability to manage change. Survey studies are conducted with a sample selected from the target population to examine a situation in depth in a certain time period, by questionnaires or interview method (Christensen, Johnson, \& Turner, 2015).

\subsection{Population and Sample}

The universe of this research consists of 4025 teachers working in primary, secondary and high schools in Uşak City Center and districts in the 2019-2020 academic year. While determining the sample size, the theoretical sample size chart was used. In studies with populations between 1000 and 3000, it is considered sufficient for the sample size to be minimum 300 people for 95\% confidence level and 5\% tolerance level (Balc1, 2011). For this reason, the sample of the research consists of 290 teachers working in primary, secondary and high schools in Uşak province, which was selected by simple random sampling method. 


\begin{tabular}{llcc}
\hline \multicolumn{2}{c}{ Table 1: Distribution of participants regarding their personal characteristics } \\
\hline Variable & & $\mathbf{n}$ & \% \\
\hline \multirow{2}{*}{ Gender } & Female & 167 & 56.6 \\
\cline { 2 - 4 } Branch & Male & 128 & 43.4 \\
\hline \multirow{4}{*}{ Year of Seniority } & Classroom teacher & 113 & 38.3 \\
\cline { 2 - 4 } & Branch teacher & 182 & 61.7 \\
\hline \multirow{3}{*}{ Educational Status } & $1-5$ & 31 & 10.5 \\
\hline & 6-10 & 48 & 16.3 \\
\hline & $11-15$ & 71 & 24.1 \\
\hline \multirow{3}{*}{ Year of Seniority in the Same School } & 16 years and above & 145 & 49.2 \\
\cline { 2 - 4 } & Associate Degree & 12 & 4.1 \\
\cline { 2 - 4 } & Bachelor's Degree & 244 & 82.7 \\
\cline { 2 - 4 } & Master's Degree & 39 & 13.2 \\
\cline { 2 - 4 } & 6-10 & 99 & 39.7 \\
\cline { 2 - 4 } & $11-15$ & 63 & 21.4 \\
\hline
\end{tabular}

As seen in Table 1, it is seen that $56.6 \%$ of the teachers who make up the sample are female and $43.4 \%$ are male, most of the teachers are branch teachers $(61.7 \%)$ and mostly have 16 years or more seniority. In addition, it is seen that the majority of the teachers $(82.7 \%)$ have undergraduate education level and the majority of them (73.3\%) are 1-10 years in terms of teaching at their school.

\subsection{Data Collection Tools}

Research data were collected with a questionnaire consisting of three parts. In the first part, there are 6 questions to determine the personal information of the participants. The other two sections consist of the scales given below. Education Manager 21st century skills Scale: It is a 21st century skill scale for Education Manager developed by Çoban, Bozkurt, and Kan (2019). The scale is a 3-dimensional scale, each of which consists of subdimensions. Four in the Dimension of Learning and Innovation Skills; There are three sub-dimensions in the "Literacy Skills Dimension" and four sub-dimensions in the "Life and Professional Skills Dimension". Cronbach's alpha reliability coefficients were calculated as 0.99 for the whole scale, 0.98 for the "learning and innovation skills" subdimension, 0.95 for the "literacy skills" sub-dimension, and 0.98 for the "life and professional skills" sub-dimension, respectively. The Change Management Competence Scale of School Administrators: The other scale is the Change Management Competence Scale developed by Helvacı (2004).

The Cronbach's alpha reliability coefficient calculated for the sub-dimension of "Detecting the Need for Change of School Administrators" is 0.97, the reliability coefficient of Cronbach's alpha is 0.98 for the sub-dimension of "Preparing for Change of School Administrators", Cronbach alpha reliability coefficient is 0.98 for the "Subdimension of Implementing Change of School Administrators", Cronbach's alpha reliability coefficient for " was calculated as 0.98 . 


\subsection{Data Analysis}

In order to determine the analyzes to be carried out in order to answer the research questions, first of all, the normal distribution of the data was examined. It was determined that the data showed normal distribution. In the analysis of the data, firstly, descriptive analyzes (arithmetic mean, standard deviation) were used to determine the level of school administrators' 21st century skills and their efficacy in managing change. Afterwards, correlation analysis was conducted to reveal the relationship between school administrators' levels of 21st century skills and their ability to manage change.

\section{Findings}

The descriptive statistics values of school administrators' level of having 21st century skills and their competencies in managing change according to teachers' opinions are presented in Table 2.

Table 2: Descriptive statistics on school administrators' level of 21st century skills and their competencies in managing change according to teachers' opinions

\begin{tabular}{|c|c|c|c|c|c|}
\hline Scale & Variable & & n & $\bar{x}$ & SS \\
\hline \multirow{15}{*}{ 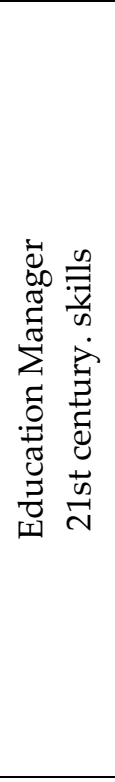 } & \multirow{5}{*}{$\begin{array}{l}\text { Sub-Dimension 1: } \\
\text { Learning and Innovation Skills }\end{array}$} & Creativity and Innovation & 295 & 3,47 & ,80 \\
\hline & & Critical Thinking and Problem Solving & 295 & 3,41 & ,78 \\
\hline & & Communication & 295 & 3,65 & ,72 \\
\hline & & Collaboration & 295 & 3,58 & ,72 \\
\hline & & Sub-Dimension Average & 295 & 3,53 & ,73 \\
\hline & \multirow{4}{*}{$\begin{array}{l}\text { Sub-Dimension 2: } \\
\text { Literacy Skills }\end{array}$} & Information Literacy & 295 & 3,60 & ,71 \\
\hline & & Media Literacy & 295 & 3,65 & ,66 \\
\hline & & Technology Literacy & 295 & 3,70 & 68 \\
\hline & & Sub-Dimension Average & 295 & 3,65 & ,65 \\
\hline & \multirow[t]{6}{*}{$\begin{array}{l}\text { Sub-Dimension 3: } \\
\text { Life and Professional Skills }\end{array}$} & $\begin{array}{l}\text { Self-Management and taking } \\
\text { Initiative responsibility }\end{array}$ & 295 & 3,62 & ,72 \\
\hline & & Productivity and Accountability & 295 & 3,69 & ,70 \\
\hline & & Leadership and Responsibility & 295 & 3,63 &, 72 \\
\hline & & Social Cultural Skills & 295 & 3,58 & ,75 \\
\hline & & Sub-Dimension Average & 295 & 3,64 & ,70 \\
\hline & & Whole Scale & 295 & 3,58 &, 69 \\
\hline \multirow{5}{*}{ 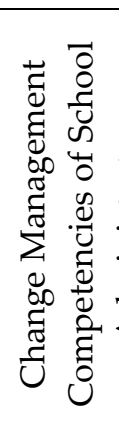 } & \multicolumn{2}{|l|}{$\begin{array}{l}\text { Sub-Dimension 1: } \\
\text { Identifying the Need for Change }\end{array}$} & 295 & 3,44 & ,75 \\
\hline & \multicolumn{2}{|l|}{$\begin{array}{l}\text { Sub-Dimension 2: } \\
\text { Preparing for Change }\end{array}$} & 295 & 3,45 & ,75 \\
\hline & \multicolumn{2}{|l|}{$\begin{array}{l}\text { Sub-Dimension 3: } \\
\text { Implementing Change }\end{array}$} & 295 & 3,48 & ,76 \\
\hline & \multicolumn{2}{|l|}{$\begin{array}{l}\text { 4. Evaluation of } \\
\text { Sub-Dimensional Change }\end{array}$} & 295 & 3,46 & ,73 \\
\hline & \multicolumn{2}{|l|}{ Whole scale } & 295 & 3,46 & 7,74 \\
\hline
\end{tabular}

As seen in Table 2, the sub-dimensions of "learning and innovation skills" (=3.53), "literacy skills" (=3.65) and "life and professional skills" (=3.64) in the context of 21st century skills 
by school administrators according to teachers' opinions It is understood that they are sufficient at the level of "very" in terms of general 21st century skills (=3.58). When the table is examined in terms of 21st century skills of school administrators; In terms of the "learning and innovation skills" sub-dimension, school administrators have the most competence in the fields of "communication" (=3.65) and "cooperation" $(=3.58)$, and the least in the fields of "critical thinking and problem solving" (=3.41). In terms of the "literacy skills" sub-dimension, school administrators have the most competence in the field of "technology literacy" (=3.70) and the least in the field of "information literacy" $(=3.60)$. In terms of the "life and professional skills" sub-dimension, school administrators have the most competence in the field of "productivity and accountability" (=3.69), and the least in the field of "social and cultural skills" (=3.58).

According to the teachers' opinions in Table 2, in the context of school administrators' competencies in managing change, "Identifying the need for change" (=3.44), "Preparing for change" (=3.45) and "Implementing change" (=3.48) and "Evaluating Change" =3.46) in terms of sub-dimensions, it is understood that they are sufficient at the level of "many". In addition, the teachers stated that they were sufficient at the "very" level in terms of the whole scale of the ability of school administrators to manage change $(=3.46)$.

Table 3 shows the correlation results for the relationship between school administrators' 21 st century skill levels and their ability to manage change.

Table 3: Correlation test results of school administrators'

21st century skill levels and their competencies in managing change

\begin{tabular}{|l|c|c|c|c|c|c|c|c|}
\hline Variable & A & A1 & A2 & A3 & B & B1 & B2 & B3 \\
\hline A. 21 $1^{\text {st }}$ Century Skills Scale Score & 1 & & & & & & & \\
\hline A1. Learning and innovation skills & $.992^{* *}$ & 1 & & & & & & \\
\hline A2. Literacy skills & $.955^{* *}$ & $.931^{* *}$ & 1 & & & & & \\
\hline A3. Life and professional skills & $.986^{* *}$ & $.968^{* *}$ & $.924^{* *}$ & 1 & & & & \\
\hline B. Change Management Skills & $.885^{* *}$ & $.882^{* *}$ & $.824^{* *}$ & $.872^{* *}$ & 1 & & & \\
\hline B1. Determining the need for change & $.853^{* *}$ & $.848^{* *}$ & $.787^{* *}$ & $.846^{* *}$ & $.961^{* *}$ & 1 & & \\
\hline B2. Prepare for change & $.855^{* *}$ & $.853^{* *}$ & $.803^{* *}$ & $.841^{* *}$ & $.975^{* *}$ & $.899^{* *}$ & 1 & \\
\hline B3. Apply the change & $.866^{* *}$ & $.864^{* *}$ & $.808^{* *}$ & $.850^{* *}$ & $.974^{* *}$ & $.897^{* *}$ & $.937^{* *}$ & 1 \\
\hline B4. Evaluating Change & $.864^{* *}$. & $862^{* *}$ & $.805^{* *}$ & $.852^{* *}$ & $.970^{* *}$ & $.898^{* *}$ & $.928^{* *}$ & $.922^{* *} 1$ \\
\hline
\end{tabular}

According to the correlation test results in Table 3., a high level of positive correlation was found between school administrators' proficiency levels regarding 21st century skills and their proficiency in managing change $[\mathrm{r}=.885, \mathrm{p}<.01]$. Similarly, between school administrators' levels of 21st century skills proficiency and the level of determining the need for change $[\mathrm{r}=.853, \mathrm{p}<.01]$, their level of preparation for change $[\mathrm{r}=.855, \mathrm{p}<.01]$, and the level of implementation of change $[\mathrm{r}=.855, \mathrm{p}<.01] .866, \mathrm{p}<.01]$, a highly significant positive correlation was found.

School administrators' proficiency levels in managing change and "learning and innovation skills" [ $\mathrm{r}=.882, \mathrm{p}<.01]$, "literacy skills" $[\mathrm{r}=.824, \mathrm{p}<.01]$ and "21st century skills" A highly significant positive correlation was found between "life and professional 
skills" [ $\mathrm{r}=.872, \mathrm{p}<.01]$. According to these results, it was determined that there is a positive and highly significant relationship between school administrators' 21st century skills and their ability to manage change.

\section{Results and Discussion}

According to the research findings, according to the teachers' opinions of school administrators working in schools affiliated to the Ministry of National Education in Uşak, 21st century skills are learning and innovation skills, literacy skills, and life and professional skills, and in all three dimensions, school administrators were found to be at a very high level of 21st century competencies. It is important for school administrators who lead education to be equipped with 21st century skills and competencies and have a vision in order to meet the expectations of the age. Considering the results, it can be said that teachers see school administrators, who are an important link in the education process, as people who attach importance to lifelong learning and can evaluate the opportunities of the age. In the study of Elekoğlu and Demirdağ (2020), it was concluded that teachers evaluate school administrators at the very level of having 21st century skills. Similarly, in the research conducted by Özdemir, Çoban, and Bozkurt (2020), school administrators It was concluded that learning and innovation skills, literacy skills, and professional and life skills, which are the main dimensions of their skills, "generally". Similarly, in Kozikoğlu and Altunova's (2018) study titled The Power of Pre-service Teachers' Self-Efficacy Perceptions Regarding 21st Century Skills to Predict Lifelong Learning Tendencies; It was concluded that self-efficacy perceptions regarding learning and renewal skills, life and career skills, and information media and technology skills, which are the sub-dimensions of the 21st century skills scale, are at a high level. In Yerli's (2009) study examining the relationship between emotional intelligence and problemsolving skills of administrators in primary and secondary schools; As a result of the analyzes made, when the level of having problem solving competence, which is a 21 st century skill, of the managers who make up the research group is examined, it is seen that they have a high level of problem solving skills. In Balıkçı's (2018) study titled The Contribution of Critical Thinking Skills to School Culture according to School Administrators, according to the observations of the researcher, participants care about critical thinking skills and adopt the same view in terms of gaining this skill. Durnalı's (2019) Technological Leadership Behavior Level of School Principals According to the Opinions of Secondary School Teachers; Technology literacy and leadership dimension, which is a 21st century skill, was evaluated and it was concluded in the study that the technological leadership behavior of school principals in the use of technology by teachers is at the level of "I agree" according to teachers' opinions. In the study of Sayrac1 and Gündüz (2018), it is seen that educational administrators have technological leadership competencies to a large extent. Based on the above findings, school administrators are generally thought to have 21st century skills. In recent years, many school administrators have been leading the STEM Education, Robotic Coding Trainings, 
Digital Literacy Trainings and Artificial Intelligence studies, which are prominent in the 21st century. The studies carried out by school administrators in this direction may have been seen positively by teachers and may have been effective in making them think that they have 21st century skills.

In the study, it was concluded that school administrators were sufficient at the level of "very" in terms of "determining the need for change", "preparing for change", "implementing change" and "evaluating change" in terms of the competence of managing change, according to the teachers' opinions. Similarly, according to Özdemir's (2019) research, administrators and school principals have a very high level of change management competencies; it has been concluded that teachers have the perception that school principals' change management competencies are generally lower than that of principals, but at a high level. When the views of both groups are considered together, it has been determined that school administrators have a high level of change management competencies. In Sayracı and Gündüz's (2018) research, it was concluded that school administrators have change management competencies at the "many" levels. Yildiz (2012) also stated in his research that from the sub-dimensions of school administrators' ability to manage change; It was concluded that they were "very adequate" in the dimensions of "Determining the need for change at school", "Preparing the school for the change process", "Implementing Change in School", and "very" in the dimensions of "Evaluating change at school". Argon and Demirer's (2015) Primary School Administrators' proficiency levels in managing change; In all dimensions of "Identifying the Need for Change at School", "Preparing the School for the Change Process", "Implementing Change at School" and "Assessing Change at School", it was concluded that "very" according to the perceptions of primary school administrators, and "moderate" according to the perceptions of teachers. In the study of Elekoğlu and Demirdağ (2020), it was determined that the transformational leadership level of school administrators is very high. Similarly, in the study of Sayrac1 and Gündüz (2018), it is seen that school administrators have many levels of competence in managing change. In the studies of Urhanoğlu (2017) and Baş (2018), it was concluded that school administrators have a high level of competence in managing change. In the study conducted by Kaşıkçı (2004), it was concluded that primary school administrators found themselves sufficient in managing change, but teachers did not find their administrators sufficient in this regard. When the findings obtained from the research are evaluated as a whole, it can be said that the change management competencies of school administrators are generally perceived at a very high level. According to the results of this research, a positive and highly significant relationship was found between school administrators' proficiency levels of 21st century skills and their proficiency in managing change. In the study of Yeni (2020), the effect of 21st century skills on the leadership aspects of school administrators were seen as positive. Similarly, a positive and highly significant relationship was found between school administrators' proficiency levels regarding 21st century skills and their levels of determining the need for change, between their levels of preparation for change, between the levels of implementing and evaluating change. According to the results, a positive 
and highly significant relationship was found between school administrators' proficiency in managing change and "learning and innovation skills" within the scope of 21st century skills, between "literacy skills" and "life and professional skills". According to these results, it has been determined that there is a positive and highly significant relationship between school administrators' 21st century skills and their ability to manage change. In the light of this result, it can be said that as school administrators' level of 21st century skills increase, their competence in managing change in schools also increases. When the literature on the subject was reviewed, no study was found that explains the relationship between school administrators' 21st century skills and change management competencies. However, similar to the subject, it is seen that there are studies that include a component of school administrators' leadership styles, 21st century skills such as problem solving, critical thinking, and technological leadership. In Ferrari's (2018) study, it was concluded that the paradigm in education continues to change, and schools continue to transform to meet the needs of societies, and the competencies of school administrators are more important than ever in the 21st century. In the light of these results, in the literature, it is seen that there are studies that overlap with our research findings, as well as studies that contradict our research findings.

\section{Recommendations}

In terms of "learning and innovation skills" sub-dimension, School principals' least have "critical thinking and problem solving" skills. For this, critical thinking and problemsolving skills trainings can be organized for school principals. According to the research results, in terms of the "life and professional skills" sub-dimension, school administrators have the least competence in the field of "social and cultural skills". In this context, school administrators can regulate the school climate in a more participatory and inclusive way. School administrators can improve their social and cultural skills by communicating and cooperating effectively with all stakeholders of the school.

This research was carried out in the province of Uşak. By conducting studies in different provinces, the results can be compared.

The universe of this study consists of teachers. Other research can be done by including school principals.

This research dealt with 21 st century competencies as a whole. Different studies can be done for each dimension of $21^{\text {st }}$ century skills.

Quantitative measurement tools were used in the study. Data can also be collected using qualitative measurement tools such as face-to-face interviews.

\section{Conflict of Interest Statement}

The authors declare no conflicts of interests. 


\begin{abstract}
About the Author(s)
Şirin Yörük is an English Teacher working as a project coordinator in Research and Development Unit of National Education Directorate of Uşak Province. She is also a graduate student in Uşak University. She studied English language teaching in Marmara University, Turkey.
\end{abstract}

Mehmet Akif Helvaci is a Prof. Dr. in Uşak University, Turkey at the faculty of Education.

\title{
References
}

Akın, U. (2014). Okul müdürlerinin inisiyatif alma düzeyleri ile öz-yeterlikleri arasındaki ilişki.Kuram ve Uygulamada Eğitim Yönetimi [Educational Administration: Theory and Practice], 20(2), 125-149. doi: 10.1457/kuey.2014.006

Altunbay, M. (2015). İlköğretim Türkçe Dersi (6-7-8. Sinıflar) öğretim programinda yer alan temel becerilerin kazandirilmasinda çocuk edebiyati ürünlerinin etkisi (21. yüzyil örneklemi). Doktora Tezi. Ankara: Gazi Üniversitesi / Eğitim Bilimleri Enstitüsü/ Türkçe Eğitimi Anabilim Dalı

Annulis, H. M., \& Gaudet, C. H. (2007). Ready or Not? Assessing Change Readiness for Implementation of the Geospatial Technology Competency Model [c]. Paper presented at the International Research Conference in The Americas of the Academy of Human Resource Development, Indianapolis

Argon T, Demirer S (2015). Okul Yöneticilerinin Bilgi Yönetimi ve İnsan Kaynaklarını Yönetim Yeterlikleri. Abant İzzet Baysal Üniversitesi Sosyal Bilimler Enstitüsü Dergisi 15(3):221-264.

Aufderheide, P. (1993). Media literacy. A report of the national leadership conference on media literacy. Washington, DC: Aspen Institute. Erişim adresi: https://eric.ed.gov/?id=ED365294. (2017, Ocak 14).

Balcı, A. (2005). Açıklamalı eğitim yönetimi terimleri sözlüğü. Ankara: Tek Ağaç Basım Yayım.

Balcı, A. (2011) Sosyal Bilimlerde Araştırma Yöntem, Teknik ve İlkeler. Pegem Yayıncılık Balıkçı, A.(2018) Okul Yöneticilerine Göre Eleştirel Düşünme Becerisinin Okul Kültürüne Katkısı.17.04. 2018 tarihinde İstanbul'da düzenlenen 2. Uluslararası Eleştirel Düşünme sempozyumunda (ISCAT 2018) sözlü bildiri olarak sunulmuştur.

Barfield, A. (2016). Collaboration. Elt Journal, 70(2), 222-224. Retrieved from https://doi.org/10.1093/elt/ccv074 on November 16, 2018.

Baş, G. (2018) Okul yöneticilerinin değişimi yönetme yeterlilikleri ile öğretmenlerde görülen değişim sinizmi arasındaki ilişki (Yüksek Lisans Tezi), Uşak Üniversitesi - Sosyal Bilimler Enstitüsü, Uşak.

Bateman, T. S., \& Snell, S. (2004). Management: The New Competitive Landscape. New York: McGraw- Hill.

Beyerlein, M. A. (1994). Theories of self-managing work teams. Greenwich: JAI Press. 
Bush, V. D.; Rose, G. M.; Gilbert, F. \& Ingram, T. N. (2001). Managing Culturally Diverse Buyer-Seller Relationships: The Role of Intercultural Disposition and Adaptive Selling in Developing Intercultural Communication Competence. Journal of the Academy of Marketing Science, 29(4), 391-404.

Ceylan, C. (2001). Örgütler için esneklik performans modeli oluşturulması ve örgütlerin esneklik analizi. Yayınlanmamış Doktora Tezi. İstanbul: İstanbul Teknik Üniversitesi, Fen Bilimleri Enstitüsü

Christensen, L. B., Johnson, R. B. ve Turner, L. A. (2015). Araştırma Yöntemleri Desen ve Analiz. (A. Aypay, Çeviri Editörü). Anı Yayıncılık, Ankara.

Conley, D. (2007). Toward A More Comprehensive Conception of College Readiness. Eugene, OR: Educational Policy Improvement Center.

Cottrell, S. (2005). Critical thinking skills: developing effective analysis and argument. New York: Palgrave McMillan.

Çoban, Ö., Bozkurt, S., Kan, A. (2019). Eğitim Yöneticisi 21. yy. Becerileri Ölçeğinin Geliştirilmesi: Geçerlik ve Güvenirlik Çalışması . Kastamonu Eğitim Dergisi , 27 (3) , 1059-1071 . DOI: 10.24106/kefdergi.2572

Dalin, P.; L. R. (1989). Organisation Theory and Design. Third Edition. West Publishing Company. San Francisco.

Drucker, P. (2014). 21. Yüzyıl için yönetim tartışmaları (T. Bahçıvangil \& G. Gorbon, Trans.). İstanbul: Epsilon

Durnalı, M. (2019). Ortaokul öğretmenlerinin görüşlerine göre okul müdürlerinin sergilediği teknolojik liderlik davranış düzeyi. Kuramsal Eğitimbilim Dergisi [Journal of Theoretical Educational Science], 12(2), 401-430.

Elekoğlu, F. and Demirdağ, S. Karaelmas Journal of Educational Sciences 8 (2020) 101117

Erginer, A. (2006). Avrupa Birliği Eğitim Sistemleri. Türk Eğitim Sistemiyle Karşılaştırmalar. Ankara: Pegama Yayıncılık

Ferrari, Jennifer Lynne, "Leading Effective Change in Schools of the 21st Century: The Attributes, Behaviors, and Practices of Effective School Principals" (2018). Dissertations. 2798.

Eryılmaz, S. ve Ulusoy, Ç. (2015). 21. Yüzyıl Becerileri IG̣ığında FATǴH Projesi Değerlendirmesi. Gazi Üniversitesi Eğitim Fakültesi Dergisi GEFAD / GUJG, 2(35), 209-229

Gibson, J. L, Ivancevich, J. M.; Donnelly, J. H. (1991). Organizations. Printed State of America. Richard D. Irwin, Inc.

Güneş, Hasan (1995). “Okullarda Örgütsel Değişme Süreci.” Yayınlanmamış Yüksek Lisans Tezi. Malatya: İnönü Üniversitesi.

Hargreves, D. H. ( 1991). The Empowered School. London: Cassel

Helvacı, M. A. (2010). Eğitim Örgütlerinde Değişim Yönetimi. Ankara: Nobel Yayın Dağıtım 
Kaşıkçı, E. (2004). "İlköğretim okulu yöneticilerinin değişimi yönetme konusundaki yeterlikleri" Yayınlanmamış Yükseklisans Tezi, Trakya Üniversitesi, Sosyal Bilimler Enstitüsü, Edirne

Kozikoğlu İ., \& Altunova N. (2018). Öğretmen adaylarının 21. yüzyıl becerilerine ilişkin öz-yeterlik algılarının yaşam boyu öğrenme eğilimlerini yordama gücü. Yükseköğretim ve Bilim Dergisi/Journal of Higher Education and Science, 8(3), 522-531. https://doi.org/10.5961/jhes.2018.293

Kuzhda, T. (2013). Etapy uspishnogo upravlinia organizatsiynymy zminamy na pidpryemstvi. [Steps for successful organizational change management at the enterprise]. Galytskyi ekonomochnyi visnyk = Galician economic bulletin, 2(41), 66-72. [in Ukrainian].

Kuzhda, T. (2016). Diagnosing resistance to change in the change management process. Economics, Management and Sustainability, 1(1), 49-59. doi:10.14254/jems.2016.11.5 .

Kuzmin, O. (Ed.) (2014). Upravlinia zminamy [Change management]. Lvivska Politechnika. Ukraine [in Ukrainian].

MEB 2023 Eğitim Vizyonu Belgesi, 2019 Ankara

Metusalem, R., Belenky, D. M., \& DiCerbo, K. (2017). Skills for Today: What We 88 Know about Teaching and Assessing Communication. Retrieved from https://www.pearson.com/content/dam/one-dot-com/one-dotcom/global/Files/efficacyand-research/skills-for-today/CommunicationFullReport.pdf on November 5, 2018

National Research Council. (2016). Education for life and work: Developing transferable knowledge and skills in the 21st century. National Academies Press

Öğretir Özçelik, A. D. (Editor), \& Tuğluk, M. N. (Editor), (2018). Ĕ̆itimde ve Endüstride 21. Yüzyıl Becerileri. Ankara: Pegem Yayınevi.

Orhan-Göksün, D. ve Aşkım-Kurt, A. (2017). Öğretmen adaylarının 21. yy. öğrenen becerileri kullanımları ve 21. yy. öğreten becerileri kullanımları arasındaki ilişki. Eğitim ve Bilim, 42(190). DOI: 10.15390/EB.2017.7089.

Özdemir, A. (2019) Öğretmen Ve Müdür Algılarına Göre Okul Müdürlerinin Değişim Yönetimi Yeterlikleri Ve Liderlik Stilleri Yüksek Lisans Tezi. Muğla: Sıtkı Koçman Üni. Eğitim Bilimleri Enstitüsü

Özdemir, S., Çoban, Ö., \& Bozkurt, S. (2020). Examination of the relationship between school principals' 21st century skills and their strategic leadership according to teachers' opinions. Pegem Eğitim ve Öğretim Dergisi, 10(2), 399-426. http://dx.doi.org/10.14527/pegegog.2020.014

Özkara, B. (1999) Evrimci ve devrimci örgütsel değişim. Afyon: Afyon Üniversitesi.

P21, The Partnership for 21st Century Learning (P21), http://www.p21.org/, Erişim Tarihi:21-12-2019

Partnership for 21st Century Skills. (2008). 21 st. century skills, education and competitiveness. Tucson, AZ: Author 
Pashchenko, O. (2014). Suchasni metody upravlinia zminamy na pidpryemstvi [The modern methods of change management at the enterprise]. Visnyk Zhytomyrskogo derzhavnogo technologichnogo universytetu $=$ Zhytomyr State Technological University Bulletin, Series Economic Science, 3, 170-178. [in Ukrainian

Sayracı, N., \& Gündüz, H.B. (2018). Okul yöneticilerinin değişimi yönetme yeterlilikleri ve teknolojik liderliği. YILDIZ Journal of Educational Research, 3 (1), 27-61.

Schalk Rene, Campbell Jennifer W. and freese Charissa (1998). “Change and Employee Behaviour", Leadership \& Organization Development Journal, Vol. 19, No. 3, p.157-163

Schater, M. (2000). When Accountability Fails: A Framework for Diagnosis and Action Policy Brief. Canada: Institute on Governance.

Shackelford, R. (2007). Technological literacy: A new basic for inclusion in the university's core curriculum. University College Cork, Ireland.

Sheffield, L. (2013). Creativity and school mathematics: some modest observations. ZDM, $45(2), 325-332$.

Stepanenko, S.V. (2016). Formuvania mechanizmu upravlinia organizatsiynymy zminamy [Formation of organizational change management mechanism]. Actual problems of innovative economy, 3, 60-67. [in Ukrainian].

Surowiecki, J. (2005). The wisdom of crowds. Anchor Books: USA

TDK. (2000). Okul Sözlügü. Türk Dil Kurumu. Ankara: Türk Dil Kurumu Yayinlari No: 603.

TTKB (2017). Müfredatta Yenileme ve Değişiklik Çalışmalarımız Üzerine... https://ttkb.meb.gov.tr/meb iys dosyalar/2017 07/18160003 basin aciklamasiprogram.pdf. Erişim: 25.03.2019

Urhanoğlu, İ. (2017) Okul yöneticilerinin değişimi yönetme yeterlilikleri Afyonkarahisar ili örneği (Yüksek Lisans Tezi). Uşak Üniversitesi Sosyal Bilimler Enstitüsü, Uşak.

Uslu, D.,2006. Örgütlerde değişim ve değişim sürecinin işgörenlerce algılanması üzerine bir alan araştırması Sağlık Bakanlığı Ankara Eğitim ve Araştırma Hastanesi örneği. Yüksek Lisans Tezi. Ankara: T.C.Gazi Üniversitesi Eğitim Bilimleri Enstitüsü. ss.639.

Ülgen, Hayri; İşletmelerde Organizasyon İlkeleri ve Uygulamaları, 2. Baskı, İstabul; 1993

Yeni, G. (2020). 21. Yüzyıl Becerilerinin Okul Yöneticilerinin Liderlik Yönlerine Olan Etkisi. Uluslararası Liderlik Eğitim Dergisi.(ULEAD).Cilt (sayı)2-2.

Yerli, S. (2009). İlk ve orta öğretim okullarındaki yöneticilerin duygusal zeka ve problem çözme becerileri arasındaki ilişki, İstanbul Anadolu Yakası örneği (Yayımlanmamış Yüksek Lisans Tezi). Maltepe Üniversitesi, Sosyal Bilimleri Enstitüsü, İstanbul.

Yıldız, K. (2012). Yöneticilerin değişimi yönetme yeterlikleri. AİBÜ Sosyal Bilimler Enstitüsü Dergisi, 12 (2), 177-198 
Zurkowski, P. G. (1974). The information service environment: relationships and priorities. (Report ED 100391). Washington DC: National Commission on Libraries and Information Science.

Author(s) will retain the copyright of their published articles agreeing that a Creative Commons Attribution 4.0 International License (CC BY 4.0) terms will be applied to their work. Under the terms of this license, no permission is required from the author(s) or publisher for members of the community to copy, distribute, transmit or adapt the article content, providing a proper, prominent and unambiguous attribution to the authors in a manner that makes clear that the materials are being reused under permission of a Creative Commons License. Views, opinions and conclusions expressed in this research article are views, opinions and conclusions of the author(s). Open Access Publishing Group and European Journal of Education Studies shall not be responsible or answerable for any loss, damage or liability caused in relation to/arising out of conflicts of interest, copyright violations and inappropriate or inaccurate use of any kind content related or integrated into the research work. All the published works are meeting the Open Access Publishing requirements and can be freely accessed, shared, modified, distributed and used in educational, commercial and non-commercial purposes under a Creative Commons Attribution 4.0 International License (CC BY 4.0). 